We welcome your reflections at http://www.AnnFamMed.org.

\section{References}

1. Kaufman A. Theory vs practice: should primary care practice take on social determinants of health now? Yes. Ann Fam Med. 2016;14(2):100-101.

2. Solberg LI. Theory vs practice: should primary care practice take on social determinants of health now? No. Ann Fam Med. 2016;14(2):102-103.

3. DeVoe JE, Bazemore AW, Cottrell EK, et al. Perspectives in primary care: a conceptual framework and path for integrating social determinants of health into primary care practice. Ann Fam Med. 2016;14(2):104-108

4. IOM (Institute of Medicine). Capturing Social and Behavioral Domains in Electronic Health Records: Phase 1. Washington, DC: The National Academies Press; 2014

5. IOM (Institute of Medicine). Capturing Social and Behavioral Domains and Measures in Electronic Health Records: Phase 2. Washington, DC: The National Academies Press; 2014.

6. Ferrer RL, Burge SK, Palmer RF, Cruz I. Practical opportunities for healthy diet and physical activity: relationship to intentions, behaviors, and body mass index. Ann Fam Med. 2016;14(2):109-116.

7. Mercer SW, Higgins M, Bikker AM, et al. General practitioners' empathy and health outcomes: a prospective observational study of consultations in areas of high and low deprivation. Ann Fam Med. 2016;14(2):117-124
8. Mercer SW, Watt GC. The inverse care law: clinical primary care encounters in deprived and affluent areas of Scotland. Ann Fam Med. 2007;5(6):503-510.

9. Lum HD, Jones J, Matlock DD, et al. Advance care planning meets group medical visits: the feasibility of promoting conversations. Ann Fam Med. 2016;14(2):125-132.

10. Olayiwola JN, Anderson D, Jepeal N, et al. Electronic consultations to improve the primary care-specialty care interface for cardiology in the medically underserved: a cluster-randomized controlled trial. Ann Fam Med. 2016;14(2):133-140.

11. Cabral C, Ingram J, Lucas PJ, et al. Influence of clinical communication on parents' antibiotic expectations for children with respiratory tract infections. Ann Fam Med. 2016;14(2):141-147.

12. Greene J, Hibbard JH, Alvarez C, Overton V. Supporting patient behavior change: approaches used by primary care clinicians whose patients have an increase in activation levels. Ann Fam Med. 2016;14(2):148-154

13. Metheny N, Stephenson R. Disclosure of sexual orientation and uptake of HIV testing and hepatitis vaccination for rural men who have sex with men. Ann Fam Med. 2016;14(2):155-158.

14. Khanassov V, Vedel I. Family physician-case manager collaboration and needs of patients with dementia and their caregivers: a systematic mixed studies review. Ann Fam Med. 2016;14(2):166-177.

15. Rollow W, Cucchiara P. Achieving value in primary care: the primary care value model. Ann Fam Med. 2016;14(2):159-165.

\title{
Thank you, Reviewers and E-letter Contributors!
}

Ann Fam Med 2016;14:99. doi: 10.1370/afm.1928.

We would like to extend our thanks to 2 groups who provide invaluable insights to the Annals of Family Medicine.

Peer reviewers are key to advancing scholarship and contributing to the quality of a research journal.

We are grateful to the many individuals who volunteer their time and expertise in this important endeavor. Please see http://www.annfammed.org/site/misc/reviewers15.xhtml for the names of the Annals' 2014-2015 peer reviewers.

The Annals is also enriched by those who contribute e-letters. In 2015 we posted more than 150 e-letters reflecting on a wide range of published articles. Our sincere thanks to those who participated in this stimulating dialogue. To read e-letters, click on "View comments" on the right-hand side of any article or visit http:// www.annfammed.org/ and click on "TRACK Discussion."

\section{CORRECTION}

Ann Fam Med 2016;14:99. doi: 10.1370/afm.1914.

The degree of MD was erroneously added to Jayme L. Mendelsohn, MPH in the author listing for: Casalino LP, Chen MA, Staub C, et al. Large independent primary care medical groups. Ann Fam Med. 2016;14(1):16-25. A new PDF will be uploaded and the online version will therefore differ from the print version of the article. 